\title{
RESEARCHES ON AERATION OF STAGNANT WATER OR FLOWING THROUGH PIPES
}

\author{
Titu-Cătălin Cioienaru1, Octavian Donțu², Nicolae Băran³, \\ Nicoleta Albu ${ }^{4}$, Alexandru Gavrilă $\breve{5}^{5}$ Mihaela Petroșel ${ }^{6}$, \\ Mihaela Constantin 7 , Corina Moga ${ }^{8}$ \\ 1:7University Politehnica of Bucharest \\ Splaiul Independenței no. 313, sector 6, Bucharest \\ ${ }^{8}$ DFR Systems SRL, Bucharest, Romania \\ E-mail:cioie94@gmail.com,octavdontu@yahoo.com,n baran fimm@yahoo.com \\ nicoleta681105@yahoo.com,corinamoga@yahoo.com,i.mihaelaconstantin@gmail.com
}

\begin{abstract}
The paper presents two experimental installations that will be used to measure the dissolved oxygen concentration in wastewater. The first installation refers to stagnant wastewater and the second to wastewater flowing through pipes. The sketches of the two installations, the fluids circulation and the measuring devices are presented. The results of the theoretical and experimental researches regarding the increase of the dissolved oxygen content in water in the case of the two experimental installations will be presented in a subsequent paper.
\end{abstract}

Keywords: Water Aeration, Fine Bubble Generators, Air Dispersion in Water.

\section{Introduction}

The hydrodynamics of two-phase gas-liquid systems is of great scientific and technical importance by applying it to wastewater aeration.

Aeration can be performed in three ways [1] [2] [3]:

a) mechanical aeration;

b) pneumatic aeration;

c) mixed aeration $(a+b)$.

Pneumatic aeration is most commonly encountered in practice and can take place in the following ways [4] [5]:

1) By introducing air in the water with the help of drilled pipes mounted on the water tank;

2) By using porous diffusers whose membrane is made of ceramic, elastic or plastic materials;

3) By using fine air bubble generators that have a perforated plate with orifices achieved by unconventional technologies [6] [7].

Air dispersion devices in water are also classified according to the diameter of the produced bubbles [8] [9]:

- Devices that produce fine bubbles: $\emptyset \leq 1 \mathrm{~mm}$;

- Devices that produce medium bubbles: $\emptyset=1 \ldots 3 \mathrm{~mm}$;

- Devices that produce large bubbles: $\emptyset=3 \ldots 120 \mathrm{~mm}$.

In order to intensify the phenomenon of airwater interphase transfer [10] [11] it is necessary to achieve a maximum interfacial contact surface, bubbles of the smallest diameter must be produced.
Aluminium perforated plates were made in UPB laboratories, where the air dispersion orifices have diameters of $0.1 \mathrm{~mm} 0.3 \mathrm{~mm} 0.5 \mathrm{~mm}$.

The fine bubble generators with perforated metal plate have the following advantages [12] [13] [14]:

- ensures a uniform distribution of air bubbles, according to the designer's request;

- ensures an approximately equal size of the air bubbles diameter introduced into the water;

- the pressure loss that appears when passing through the fine bubble generators (FBG) is much lower than the ones of the porous diffusers which leads to an energy saving;

- FBG have a high reliability in operation, is easily cleaned by compressed air inlet at pressures higher than the operating pressure.

\section{Air Injection in Stagnant Water Using Fine Bubble Generators}

The fine bubble generator is provided with a plate with orifices which must meet certain conditions [15] [16] (figure 1).

The aluminium plates thickness is $\mathrm{s}=2 \mathrm{~mm}$, and the distance between the orifices is $\mathrm{d}=6 \mathrm{~mm}$.

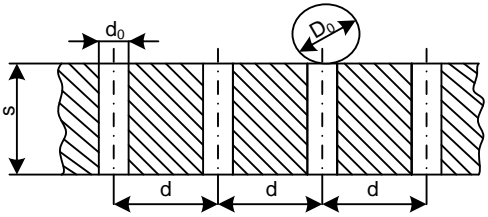

Figure 1: Plate with orifices for air dispersion in stationary waters 


$$
\begin{aligned}
& \text { I) } \frac{s}{d_{0}}>3 \\
& \text { II) } \frac{d}{d_{0}}>8
\end{aligned}
$$

For $\mathrm{d}_{0}=0.3 \mathrm{~mm}$ :

$$
\begin{gathered}
\frac{s}{d_{0}}=\frac{2}{0.3}=6.66>3 \\
\frac{d}{d_{0}}=\frac{6}{0.3}=20>8
\end{gathered}
$$

One can see that both conditions were met.

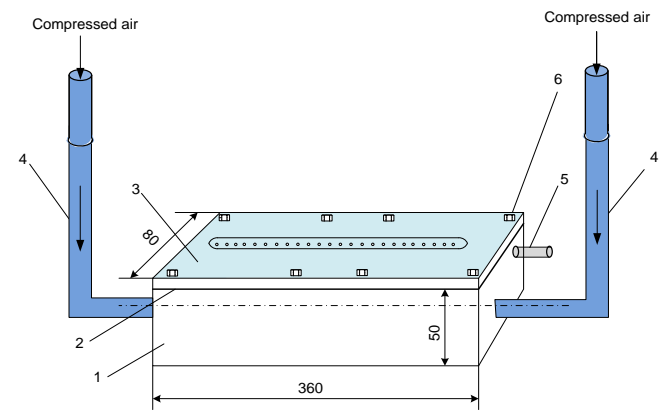

Figure 2: Fine air bubble generator

1 - compressed air tank; 2 - sealing gasket; 3 - orifice plate; 4 -compressed air supply pipe of FBG;

5 - compressed air pressure connection; 6 - screws for fixing the plate with orifices on the tank frame

Figure 2 shows an overview of the fine air bubble generator having a plate with 17 orifices $\varnothing 0.3 \mathrm{~mm}$ [17].

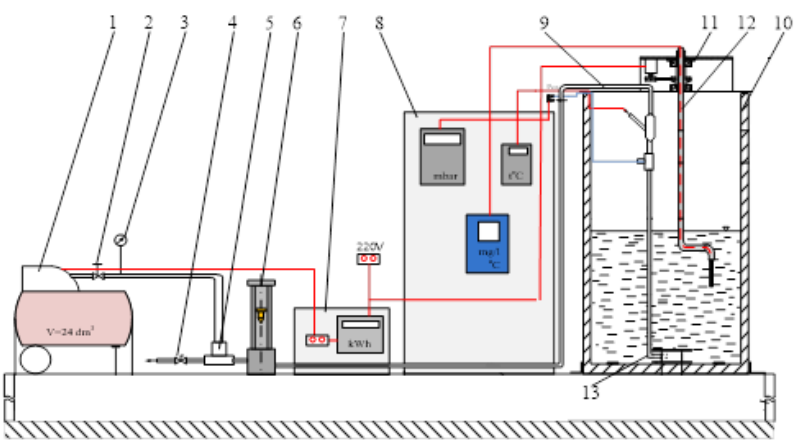

Figure 3: Sketch of the experimental installation

1- electro compressor with air tank;

2 - pressure reducer; 3-manometer; 4 - connection for the discharge of air into the atmosphere; 5- T-joint;

6-rotameter; 7-electrical panel; 8-panel with

measuring devices; 9- pipe for the transport of compressed air to FBG; 10-water tank;

11 - mechanism for actuating the probe; 12-oxygen sensor; $13-F B G$

This fine bubble generator (figure 2) was inserted into the water tank of figure 3.

\section{Air Injection into Water Flowing Through Pipes}

Air injection may occur in: 1 - horizontal pipes or 2 vertical pipes.

In the following, only point 1 is studied in the following sense: for the same initial data as in version 1 , an installation was designed to ensure the increase of dissolved oxygen concentration in water flowing in horizontal pipes.

Water flows from a tank through a transparent plexiglass pipe $\varnothing 50 \times 2 \mathrm{~mm}(8)$.

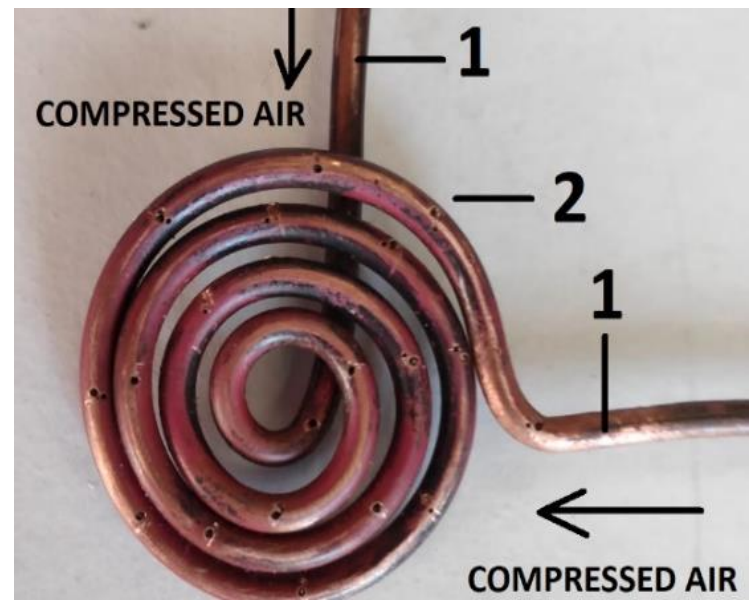

Figure 4: Flat serpentine provided with 17 orifices 1- connection for compressed air; 2-orifices $\emptyset 0.3 \mathrm{~mm}$.

The water flow rate is measured at the outlet of the tank with the flow meter (7) and subsequently in the pipe flange (9) is a serpentine in where compressed air is introduced (figure 4).

The serpentine is provided with $17 \varnothing 0.3 \mathrm{~mm}$ orifices through which the air comes out and circulates in an equilibrating manner with water; the serpentine is supplied with compressed air through the two records (1). According to the estimates, it is possible that by mixing air + water, after a distance of 2 meters the saturation concentration $\left(C_{s}\right)$ of the oxygen dissolved in water to be reached (figure 5).

If not, a second serpentine supplied with compressed air by the valve tap (14') is inserted in the second flange ( 9 ').

The sensors (11) will detect and indicate the dissolved oxygen concentration in water [18] at the oxygen meter (12).

The compressed air supplied by an electro compressor passes through a rotameter and through the valves 14 and 14 ' enters the two serpentines.

In order to study the influence of some parameters (water speed, air speed, air flow rate, etc.) on the water aeration process, the 34 orifices were distributed in two circular wreaths mounted between the pipe flanges $(9 ; 9$ ') at the distance of $2000 \mathrm{~mm}$ (Figure 5). 


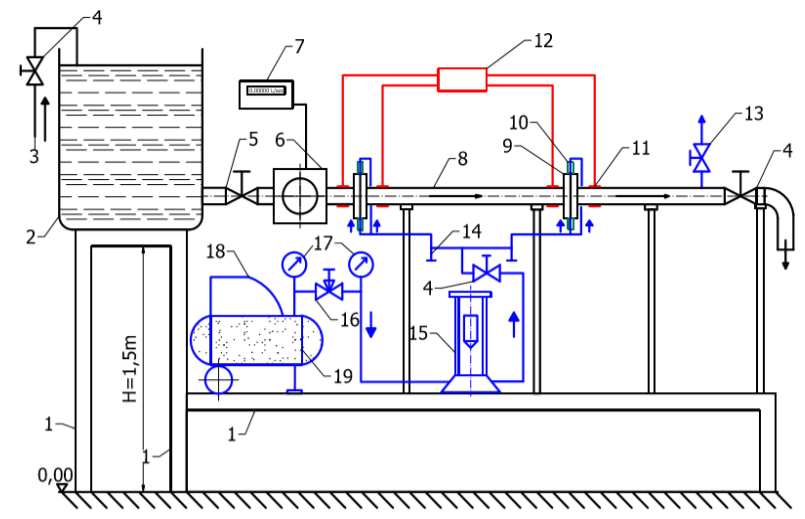

Figure 5: Sketch of the experimental installation 1-supports; 2-water tank; 3-water supply from the network; 4- sleeve valve; 5- ball check valve; 6- sensor;

7-flow meter; 8- pipe Ø 50x2; 9-flanges; 10 connection the spiral; 11-sensors; 12-oxygen meter; 13-vent valve; 14- angle valve; 15 -rotameter; 16- air

flow control valve; 17-manometers; 18 - electro compressor; 19- compressed air tank

Figure 6 shows an overview of the experimental installation for determining the dissolved oxygen concentration in water flowing through pressure pipes.

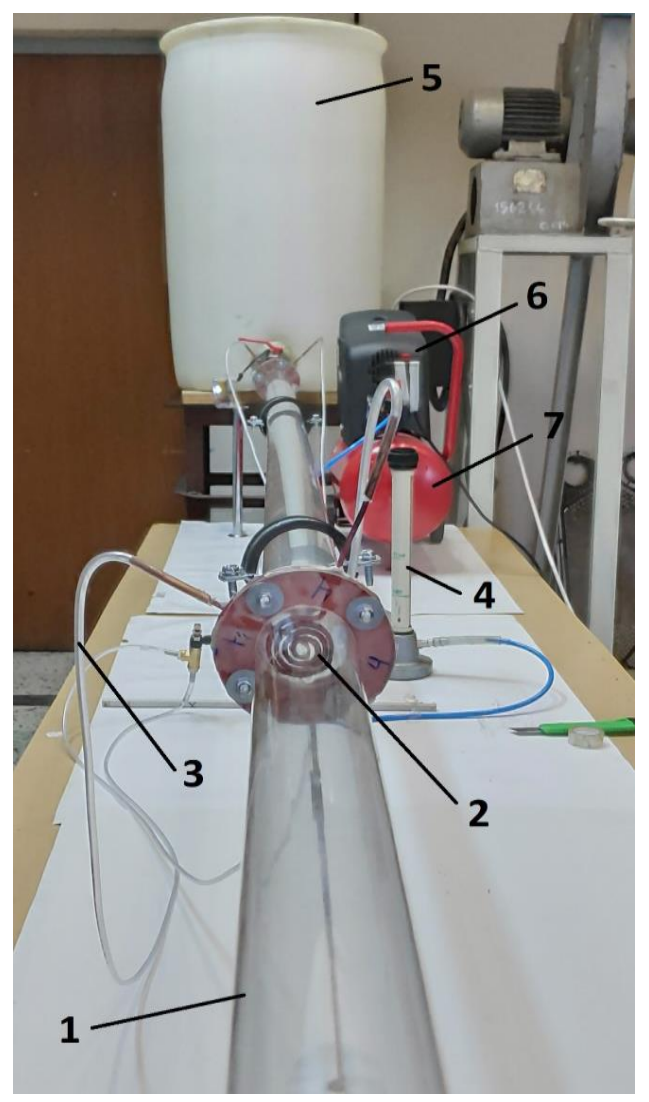

Figure 6: Overview of the experimental installation 1- transparent plexiglass pipe; 2 - serpentine mounted inside the pipe flange; 3-compressed air connection for the serpentine; 4- rotameter; 5-water tank; 6- electro compressor; 7-compressed air tank
Figure 7 shows a detail of the device for measuring the water flow rate with an electronic meter.

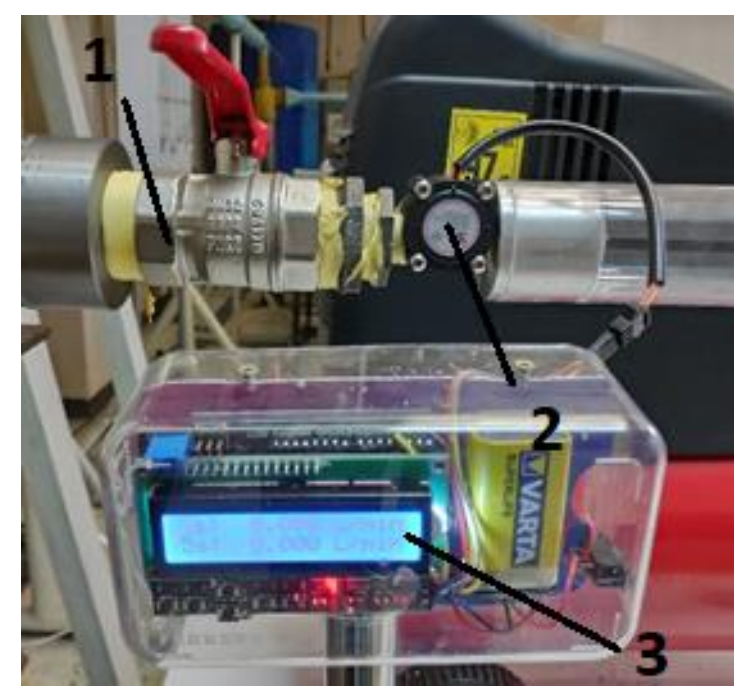

Figure 7: Measuring the water flow rate flowing through the pipe $\varnothing 50 \times 2 \mathrm{~mm}$.

1- water flow rate control valve; 2 -flow rate sensor; 3-flow meter

In figure 8 one can observe how a spiral (1) is mounted inside the transparent plexiglass pipe through which the compressed air enters the water and moves in an equilibrating manner with water.

Figure 8 show that the compressed air enters the spiral (1) through two connections (2).

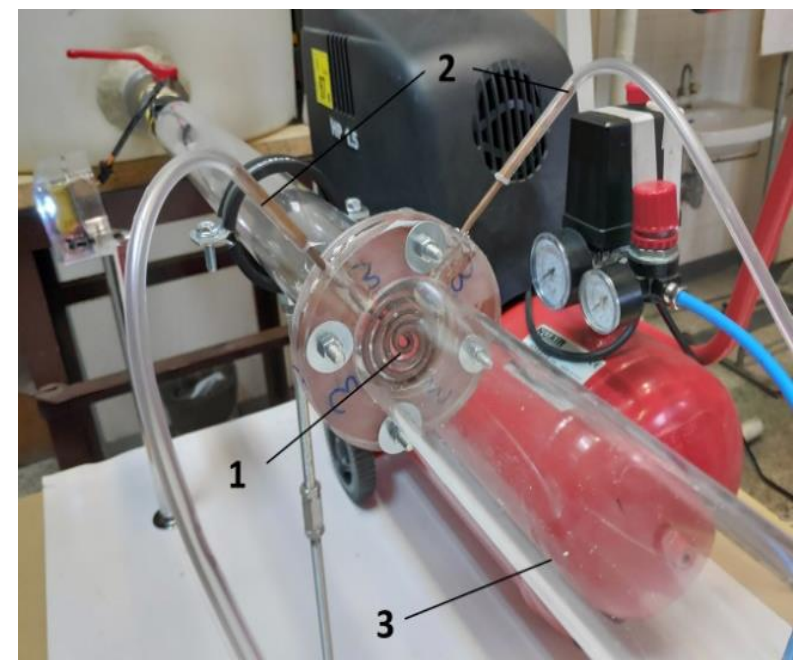

Figure 8: General view of the serpentine supplied with compressed air through two capillary tubes $\emptyset 3 \times 1 \mathrm{~mm}$.

1- spiral; 2-connections for the introduction of compressed air; 3-transparent plexiglass tube

The flow pipe of the two-phase fluid, air plus water, is made of $50 \times 2 \mathrm{~mm}$ plexiglass from Germany. The pipe allows the measurement of the dissolved oxygen concentration in water by one of three methods: [19] [20] [21], namely by the optical method which is a non-invasive method. 


\section{Conclusions}

A) the paper presents two installations used to aerate the waters in two situations:

- stagnant water, i.e. stationary water in which compressed air is introduced with the help of a compressor;

- waters flowing in pressure pipes for which the air is introduced through a serpentine mounted in the pipe; the injected air circulates in an equilibrating manner with water.

B) the cost of the expenses to build a FBG or a serpentine is about the same.

C) by introducing air into horizontal pipes (the first stage of the researches), the aeration tanks can be removed from the water treatment stations, thus reducing the value of the investments.

D) the pressure loss that occurs when air is passed through the fine bubble generators provided with flat metal plates is lower than in the porous diffusers [22] [23] which leads to energy savings [24] [25].

E) experimental researches will demonstrate that it is more technically and economically efficient.

F) the aeration of the water flowing through vertical pipes will be studied later, this is the second stage of the researches on water aeration.

\section{Acknowledgements}

This work was supported by a grant of the Romanian National Authority for Scientific Research and Inovation, CCDI - UEFISCDI, project number Manunet - MINET 17/ENER 2307-CEBIOTREAT within PNCDI III.

\section{References}

[1] G. Băran, I. Pincovschi, G. Oprina,, Hidro-GazoDinamica Sistemelor de aerare echipate $\mathrm{cu}$ generatoare de bule, Ed. POLITEHNICA PRES, Bucureşti 2009;

[2] D. Robescu, D. L. Robescu, A. Verestoy, Fiabilitatea proceselor, instalaţiilor şi echipamentelor de tratare şi epurare a apelor, Ed. Tehnică, Bucureşti, 2002;

[3] D. L. Robescu, S. Lanyi, A. Verestoy, D. Robescu, Modelarea şi simularea proceselor de epurare, Ed. Tehnică Bucureşti, 2004;

[4] G. M. Mateescu, Hidro-gazo-dinamica generatoarelor de bule fine, Teză de doctorat, Universitatea POLITEHNICA din București, Facultatea de Mecanică şi Mecatronică, Bucureşti, 2011;

[5] Tănase Betrice Elena."Influența compoziției gazului insuflat în apă asupra conținutului de oxigen dizolvat". Teză de doctorat, Universitatea Politehnica din București, 2017;

[6] O. Donțu, Tehnologii și sisteme de fabricație utilizate în mecatronică, Editura Printech București, 2014;
[7] B. Tănase , D. Besnea , R. Mlisan , M. Constantin and N. Băran, Constructive solutions for the achievement of fine bubble generators based on micro-drilling technologies, IJISET - International Journal of Innovative Science, Engineering \& Technology, Vol. 2 Issue 2, 2015, pp. 46-50

[8] Schierholz E.L., Wilhem S.C., Henneman H.E., Gas transfer from air diffusers, Water Research, vol 40, p.1018-1026, 2006

[9] M. Căluşaru, N. Băran, Al. Pătulea, Researches regarding the transfer of oxygen in water, The 3rd International Conference on Mechanic Automation and Control Engineering (MACE 2012) July 27th -29th, published by IEEE Computer Society CPS, and then submitted to be indexed by Ei Compendex, Baotou, China, 2012, pp. 2617-2620;

[10] P.V. Danckwerts, "Significance of Liquid-Film Coeficient in Gas Absortion", Ind. En. Chem., vol. 43, No.6, pp. 1460-1467, 1995;

[11] Ly. Nguyen, R.G. Carbonell and B.J. McCoy, "Diffusion of Gases through Surfactant Film : Interfacial Resistance to Mass Transfer," AIChE J_., vol.25, No .6, pp .1015-1024, 1979;

[12] Ionela Mihaela Căluşaru, Nicolae Băran and Alexandru Pătulea, The influence of the constructive solution of fine bubble generators on the concentration of oxygen dissolved in water, Advanced Materials Research Vols. 538541 (2012) pp 2304-2310;

[13] Nicolae Băran, Gheorghe Băran, Gabriela Mateescu, Alexandru Sorin Pătulea, Water Oxigenaţion, Buletinul Institutului Politehnic din Iaşi tom XI (LX) fasc.3b., ISSN. pag / 77-84, Ed. Politehnium 2010;

[14] N. Băran, A. Pătulea, G. Băran, Experimental Researches Regarding The Obtain Of Curtains Of Fine Air Bubbles, A şasea conferinţă a Hidroenergeticienilor din românia Dorin Pavel, 27-28 mai, 2010, pag.23 -32, Bucureşti;

[15] Al. S. Pătulea, Influenţa parametrilor funcţionali şi a arhitecturii generatoarelor de bule fine asupra eficienţei instalaţiilor de aerare, Teză de doctorat, Universitatea Politehnica din București, 2012;

[16] T. Miyahara, Y.Matsuha, T. Takahashi, The size of bubbles generated from perforated plates, International Chemical Engineering, vol. 23, 1983, pp. 517-523;

[17] Rasha Mlisan The influence of fine bubbles generators architecture on the dissolved oxygen concentration in water Phd. Thesis Bucharest Politehnica University of Bucharest 2017;

[18] Pătulea, N. Băran, I. Căluşaru, Measurements of Dissolved Oxygen Concentration in Stationary Water, World Environment (Scientific \& Academic Publishing), Rosemead, CA, 91731, USA, 2012; vol. 2(5), pp. 104-109; 
[19] A. Pătulea, I. Căluşaru, N. Băran, Reasearches regarding the measurements of the dissolved concentration in water, Advanced Materials Research, Trans Tech Publications, Switzerland, 2012, Vols. 550-553, pp 3388-3394;

[20] I. M. Căluşaru, A. Costache, N. Băran, G. L. Ionescu, O. Donţu, The determination of dissolved oxygen concentration in stationary water, Applied Mechanics and Materials, Trans Tech Publications, Switzerland, vols. 436, 2012, pp. 233-237;

[21] M. K. Stenstrom, S. Y. Leu, P. Jiang, Theory to Practice: Oxygen Transfer and the New ASCE Standard, Water Environment Foundation, 2006;

[22] G.Oprina, Contribuţii la hidro-gazo-dinamica difuzoarelor poroase, Teză de doctorat, Universitatea Politehnica din Bucureşti, Facultatea de Energetică, 2007;
[23] Mihaela Constantin, Nicolae Băran, Rares Păun, Giovani Roza, Theoretical and Experimental Researches about the Pressure Loss of a New Type of Fine Bubble Generator, International Journal of Emerging Research in Management \&Technology ISSN: 2278-9359 (Volume-6, Issue-2) February 2017, pp115-120 (BDI; Cabell's, Google Scholar);

[24] Beatrice Tanase, Mihaela Constantin, Mădălina Zamfir, Nicolae Băran, Rareș, Albertino Roza, Energy optimization of water oxygenation processes, U.P.B. Sci. Bull., Series D, Vol. 80, Iss. 2, 2018, pag103-114;

[25] E. B. Tănase, N. Băran, M. Vlăsceanu (Banu), Reduction of energy consumption in water aeration plants , IJISET - International Journal of Innovative, Enginnering \& Technology, vol I, Issue 5, 2014, pp. 522-524. 